\title{
UM EMARANHADO DE CASOS: TRÁFICO DE DROGAS, ESTADO E PRECARIEDADE EM MORADIAS POPULARES
}

\author{
Patrícia Birman \\ Adriana Fernandes \\ Camila Pierobon
}

\begin{abstract}
"Para mim, o tráfico [de drogas] funciona igual ao Estado quando é para piorar a situação da gente". Assim disse Leandro, enquanto relatava os problemas que atingiam a ocupação Nelson Mandela, ${ }^{1}$ situada na parte antiga do centro do Rio de Janeiro. O trecho citado aproxima os efeitos deletérios das políticas públicas urbanas em curso nessa região da atuação provocada pelo tráfico de drogas que, naquele preciso momento, tinha invadido a ocupação. ${ }^{2}$ Esse diálogo, com efeito, faz referência ao contexto social e político em que está inserida esta ocupação - contexto marcado pela aliança entre governos federal, estadual e municipal com a intenção de promover a "revitalização" daquela área do Rio mediante o conhecido projeto Porto Maravilha.

Trata-se de um megaprojeto, cujos empreendimentos, como tantos documentos têm assinalado, estão alterando substantivamente o perfil urbano de uma região marcadamente popular, com o intuito de destiná-la às camadas médias e a setores empresariais e turísticos. ${ }^{3}$ Ao repertório de atuação deste projeto soma-se a política de ocupação militar de favelas nomeada de pacificação (Birman 2012; Oliveira 2014; Leite 2012, 2014; Leite \& Machado da Silva 2013). A análise das consequências produzidas por este megaprojeto tem como fio condutor o trabalho etnográfico que realizamos na ocupação Nelson Mandela. A situação que se delineou com a invasão do tráfico de drogas na ocupação, como sustentamos, é parte integrante do desmantelamento das moradias populares da região com vistas à chamada revitalização.

Do ponto de vista dos moradores e dos trabalhadores dos bairros populares, incluídos nesse projeto, é possível relacionar certas ações realizadas por pessoas envolvidas com o tráfico de drogas com aquelas promovidas por agentes do Estado, destacando-se como ambas incidem, conjuntamente, em suas condições de vida. Sabe-se que tem sido recorrente na bibliografia sobre o tema da violência na cidade uma perspectiva que situa tráfico e Estado
\end{abstract}


em campos opostos de atuação, bem como aquela que contrapõe Estado e sociedade, ou ainda, Estado e agentes privados. Contudo, as fronteiras que se estabelecem entre uns e outros no cotidiano estão longe de reiterar um antagonismo entre esses atores. ${ }^{4}$ Analisaremos como combates, alianças e formas de evitação variadas se sucedem, associando seus atores e apagando suas diferenças em certos planos e/ou reforçando-as em outros. Nossa intenção é assinalar qual a especificidade da governança dos pobres no Rio de Janeiro hoje e como seus dispositivos têm operado.

Emerge da observação e das atividades de nossos interlocutores um emaranhado de práticas, de grupos de atores e de formas de pertencimento que se sobrepõe, se conflita e se associa. Assim, muitas das situações que perfazem esse contexto produzem efeitos que envolvem diferentes graus de opacidade, contradição e indeterminação. A nossa tentativa de clarificar esse emaranhado começa pois por reconhecer que não é possível separar as linhas de uma racionalidade subjacente desses efeitos de opacidade, contradição e indeterminação. ${ }^{5}$ Essa trama de forças faz parte das formas de governança que buscamos analisar. Há uma opacidade que engendra, nos termos de Veenas Das, uma ilegibilidade (2004) ordinária sobre o que se passa nos planos e nas práticas governamentais.

A nossa intenção é - reconhecendo os prismas assumidos pelos moradores da Ocupação Nelson Mandela - explorar o que se apresentou para eles como uma relação mais estreita entre tráfico e polícia, entre tráfico e moradores e entre tráfico e o direito de uso obtido pelos ocupantes através do processo judicial. Interrogamos neste artigo a suposição de que essas fronteiras estejam legitimamente garantidas, bem como reconhecidas por seus moradores (Ferguson 2008). Trata-se de uma narrativa que destaca como certas relações sociais se encontram embebidas em uma produção constante de ilegalismos (Telles 2010; Magalhães 2013), precariedade (Rizek et al. 2011) e violência (Feltran 2010; Vianna 2014; Farias 2014; Machado da Silva 2008) envolvendo agentes e instituições do Estado, agentes do tráfico de drogas e segmentos populares. Em suma, tentamos elaborar uma etnografia das imbricações dessas forças no que concerne a uma governança dos pobres. ${ }^{6}$

As atuais políticas urbanas na cidade, como outros autores já assinalaram, revelam transformações nas formas de governar as populações pobres e os habitantes de periferias (Foucault 2008; Telles 2010; Wacquant 2008). Voltou à agenda pública do Rio de Janeiro a política de remoções (Magalhães 2013), cuja legitimidade se alimenta primordialmente da violência na cidade (Machado da Silva 2008). Junto a essa política de remoções, implementou-se um novo ordenamento das condutas no espaço público baseado em programas de controle disciplinar organizado pela municipalidade - 
o conhecido Choque de $\operatorname{Ordem}^{7}$ - e a chamada política de pacificação (UPP), estruturada na forma de um controle policial-militar das favelas, coordenado pelo governo do estado. O planejamento para as intervenções urbanas na antiga região do centro e zona portuária, notadamente favorecido por esses programas, atraiu novos atores associados a projetos imobiliários e especulativos cujo sucesso dependeria em grande parte da remoção imediata ou paulatina de seus habitantes, liberando, por conseguinte, terrenos para novas construções. ${ }^{8}$

Moradias ali existentes há várias décadas, cortiços talvez centenários, casas de cômodos, hotéis baratos, invasões de prédios abandonados, "esquecidos" por seus antigos proprietários, e ocupações transformaram-se, neste contexto, em alvos da administração pública, que orienta os megaprojetos imobiliários e a cobiça dos novos empreendedores. Estes foram incitados a ocupar espaços existentes após uma "limpeza" da área, traduzida pela retirada dos seguintes "indesejáveis": habitantes, trabalhadores, comerciantes informais e transeuntes das classes populares - condição necessária, afirmada e reafirmada publicamente, para adequar o progresso previsto à chegada de novos segmentos populacionais, mais condizentes com o perfil desejado pela reforma em curso. Esse processo, como sabemos, encontra-se estreitamente associado às reformas políticas e econômicas de corte neoliberal na cidade e em outras metrópoles.

Não é apenas o chamado movimento de gentrificação, ressaltemos, que atinge o cotidiano dos moradores pobres da zona portuária; ele não exclui, ao contrário, intensifica as formas de governar através de uma gestão diferencial dos ilegalismos (Telles 2010; Foucault 2009 [1975]), direcionada à face aparentemente mais "desordenada" do centro "decadente" da cidade. ${ }^{9}$ Trata-se de uma região habitada por uma população cujas formas de moradia, de trabalho e de sociabilidade são atravessadas pela informalidade. Essas políticas estatais, em nossa perspectiva, reatualizam e aumentam a precariedade associada à informalidade, além de situar esta população em um quadro de criminalização crescente.

Desde o início de um primeiro trabalho de campo em 2008, quando começamos a acompanhar algumas das ocupações autogestionárias de moradia popular, ouvimos boatos a respeito de interferências do tráfico de droga $\mathrm{s}^{10}$ na região e observamos a sua presença em alguns pontos de venda no asfalto. Dentre os rumores, sobressaíam aqueles que enunciavam conflitos de traficantes com moradores, ameaças dos primeiros aos segundos e acusações variadas sobre as relações existentes entre uns e outros. Os militantes das ocupações viam nessas acusações e nesses conflitos ameaças efetivas à sua continuidade como um projeto político de autogestão. A frequência e 
a intensidade de passagens do tráfico, os rumores sobre as intenções deste, seus exercícios de poder no cotidiano da vizinhança e nas proximidades das ocupações autogestionárias nos incitaram a compreender os dispositivos que acompanharam a sua presença.

Todos os moradores reconheciam o tráfico como um grupo organizado sediado em um morro próximo. A sua gerência, desde que começamos a acompanhar o cotidiano das ocupações, não se imiscuía diretamente na vida local, mas poderia ser acionada através de funcionários atuantes no asfalto. A impressão dos moradores que conhecíamos era de que o autorreferido advogado do grupo do tráfico local estava sempre circulando na área e podia intervir a qualquer momento nas situações de conflito. Mas aqueles comumente designados por nossos interlocutores como meninos do tráfico, às vezes amistosos e/ou indiferentes, às vezes ameaçadores e violentos, participavam das interações cotidianas como membros de famílias, como ocupantes dos pontos de venda em passagens movimentadas, como vizinhos participantes da sociabilidade local.

Em resumo, a chegada do tráfico na ocupação Nelson Mandela estaria indicando uma mudança na gestão diferencial dos ilegalismos nessa região, uma intensificação das formas de violência e da ilegibilidade das políticas para a camada mais pobre ali localizada e, consequentemente, uma piora nas condições de precariedade nessa cobiçada área destinada a ser moderna. ${ }^{11}$

\section{Sobrevoo: como tudo é pertinho}

A Estação Ferroviária Central do Brasil, importante terminal de trens e metrôs, de ônibus e de vans, é referência para diferentes segmentos populacionais: moradores, camelôs, ambulantes, trabalhadores que habitam a zona norte e áreas metropolitanas e também para os imigrantes que se multiplicam na cidade.

O caminho da Central do Brasil à Gamboa e adjacências é curto e movimentado. Passagens e ruas estreitas nos levam ao Morro da Providência, ao antigo camelódromo, às zonas de comércio que avançam até os marcos que hoje fazem parte do patrimônio associado a uma memória africana da cidade, como o Centro Cultural José Bonifácio, o Cemitério dos Pretos-Novos, o recém-descoberto Cais do Valongo, entre outros lugares valorizados, como o Largo da Prainha e a Pedra do Sal. Nessa pequena caminhada, a experiência é a de um lugar denso e fervilhante, inescapável àqueles que ali transitam, a começar pelo entorno da Estação Ferroviária, certamente o ponto de maior convergência das transações desse centro antigo, apresentado 
estranhamente na mídia como "vazio". ${ }^{12}$ Somos expostos a uma agitação que lembra uma praça de mercado e é acompanhada pela sonoridade das trocas e das negociações, dos anúncios e das transações que ali acontecem.

De fato, trata-se de uma área onde há um variado comércio de atacado e varejo - um grande "mercadão" popular — como outros que já existiram na cidade. Nenhum tipo de produto deixa de ser vendido ou trocado. Doces, biscoitos, roupas, relógios, materiais eletrônicos, de construção e elétrico, eletrodomésticos, bijuterias, mochilas, remédios, ervas e quinquilharias fazem parte desse circuito. Atravessam e participam dessas interações vendedores com carroças de cachorro-quente, de caldo verde, angu, caldo de ervilha, açaí, iogurtes, pipocas. Ambulantes e seus carrinhos com cachaças diversas, com água e café, quentinhas para almoço; camelôs que vendem usados de todos os tipos. Encontramos ainda depósitos de material de reciclagem, outro de venda de gelo, lojas de cosméticos, salões de beleza, restaurantes com preços módicos, botequins e o famoso restaurante municipal "Garotinho", que atende diariamente a centenas de pessoas com alimentação servida a R 1.

E mais, como em todas as regiões da cidade, há igrejas evangélicas em portas de garagem, nos casarios, em vilas e em minúsculas habitações. E como em muitos outros lugares no mundo, prostitutas vendem seus serviços e mercadorias, sobretudo a partir de 6 horas da tarde. Durante o dia, no entanto, o comércio de drogas é também visível: bocas de fumo ocupam mais pontos nas ruas depois que uma Unidade de Polícia Pacificadora (UPP) instalou-se no morro da Providência. Crianças jogam futebol no domingo, trabalhadores diversos atravessam as ruas antigas do lugar, circulando dali em direção a seus bairros, geralmente afastados do centro, chineses se encarregam de suas pastelarias, bares sempre com garrafas de catuaba (com os dizeres "revigorante" e "afrodisíaca") e máquinas de jukebox. Pois ali é também um porto para os imigrantes que chegam à cidade: angolanos, congoleses, bolivianos, haitianos. E ainda, pastores de igrejas evangélicas costumam formar círculos perto da meia-noite para pregar, atraindo sempre transeuntes, enquanto kombis de voluntários espíritas e evangélicos entregam comidas, roupas e cobertores para o pessoal da rua.

Visto que são locais onde a experiência de cidade é intensa em termos de circulação e de contato, não faltam registros históricos sobre manifestações políticas que marcaram época. Lembremos que foi nessa mesma região, a duas quadras da Estação Ferroviária, que existiu o maior cortiço da história da cidade no início do século XX, o Cabeça de Porco, que acolheu cerca de 4 mil pessoas (Chalhoub 1996). A sua destruição foi aplaudida como um sinal de apoio às reformas urbanas e higienistas da ocasião. Nessa região ocorreram também as Barricadas da Saúde, insurreição que marcou o imaginário polí- 
tico da cidade, mais conhecida como a Revolta da Vacina, em 1904, quando a população se rebelou questionando as práticas inauguradas com a ordem republicana de 1889 (Sevcenko 2003 [1983]; Lopes 2000; Chalhoub 1996).

Algumas instituições do Estado, encarregadas diretamente da gestão dos pobres e das minorias, também lá se encontram: no prédio da Estação Central do Brasil funcionam as secretarias estaduais de Segurança Pública, de Assistência Social e de Direitos Humanos. Ali também é a sede da Secretaria Especial de Ordem Pública, a chamada Secretaria do Choque de Ordem, criada em 2009 pelo prefeito do Rio, Eduardo Paes, em seu primeiro dia de mandato. ${ }^{13}$

Não bastasse a proximidade territorial entre elas, o que de fato as vincula entre si é o pertencimento a um mesmo dispositivo de controle sobre a cidade. Afinal, se na época do prefeito César Maia, “a guarda municipal agia de maneira isolada em relação às companhias fiscalizadoras específicas da cidade constituindo um modo de funcionamento não mais por ações 'a varejo' (como acontecia), mas através de ações 'a atacado': [...] agora se observa que elas estão reunidas no mesmo ambiente institucional articulando medidas de repressão" (Nacif et al. 2011:10). Para viabilizar essas ações, se "destaca a criação do Plano Municipal de Ordem Pública — PMOP" (:10). ${ }^{14}$

Em direção à região portuária, o morro da Providência teve durante certo tempo uma maior visibilidade por ter sido o local do assassinato de três jovens entregues por soldados do Exército a um grupo do tráfico oponente ao Comando Vermelho. ${ }^{15}$ Pouco tempo depois, o morro da Providência ganhou uma UPP. Por conta disso, tornou-se cenário privilegiado de mais um espetáculo midiático da pacificação. ${ }^{16}$ Foram afirmados repetidas vezes os grandes benefícios previstos para a favela com a expulsão do tráfico e a realização de obras para finalidades turísticas e urbanísticas. Destacou-se como efeito da pacificação a emergência de um campo moral renovado provocada pela saída do tráfico e a entrada de forças militares. Imagens apresentadas buscavam assegurar uma ruptura da vida no morro com o seu passado recente e a valorização do seu entorno como um espaço revitalizado.

Bairros populares, hegemonicamente investidos de emblemas que marcaram em diferentes momentos a sua suposta negatividade, hoje se veem submetidos a diagnósticos por parte de setores da governamentalidade ${ }^{17}$ muito semelhantes àqueles referentes à "promiscuidade" (dos cortiços e das ocupações), à revolta da população (e também das favelas que "descem" para o asfalto), ao "crime" (do tráfico) e à "desordem" (dos pobres e dos vendedores, das prostitutas e dos ambulantes). Seguindo o ponto de vista desses setores, clama-se hoje, como no passado, por intervenções urbanas com objetivos restauradores. 
A ocupação Nelson Mandela, situada em uma dessas ruas movimentadas, foi fundada no início dos anos 2000 por um grupo de militantes socialistas e libertários que mobilizou indivíduos que circulavam na região, como trabalhadores informais, moradores das proximidades, inclusive os que se encontravam na rua, para ocuparem um dos imóveis abandonados. Os militantes buscaram incutir pedagogicamente valores relacionados à justiça social e à igualdade no modo de autogestão que deveriam nortear a moradia coletiva. Logo em seguida à ocupação, militantes e apoiadores entraram na justiça para regularizar a posse do imóvel abandonado há mais de 20 anos, pertencente à administração federal. O imóvel abriga cerca de 70 famílias em pequenos apartamentos de um cômodo com um banheiro. Uma cozinha coletiva foi pouco a pouco substituída por cozinhas individuais.

\section{Invasão pelo tráfico e rede de apoiadores ${ }^{18}$}

Em 2013 soubemos, através de uma das principais lideranças dessa ocupação, que o tráfico teria conseguido, finalmente, invadir o prédio. Alguns garotos armados tomaram um quarto no primeiro andar e declararam que, daquele momento em diante, a ocupação seria uma boca de fumo, ou seja, um ponto de venda de drogas controlado pelo gerente do movimento. O imóvel ocupado há alguns anos, símbolo de uma ocupação que deu certo no Rio de Janeiro, teria caído. O fato emblemático dessa ocupação que deu certo foi obter o que seria a última e grande vitória: os seus moradores ganharam na Justiça o direito ao usufruto do imóvel em um contexto de numerosos despejos de outras ocupações e de remoções pela cidade. Com a entrada e o controle do tráfico, os ganhos políticos e jurídicos pareciam desmoronar. Naquele momento, o tráfico não era sinônimo de jovens que trabalhavam nas bocas de fumo (os meninos do tráfico, como habitualmente são referidos), situados na base da hierarquia e que, por vezes, por iniciativa própria, ameaçavam moradores para conseguir benefícios pessoais, como a instalação de algum menino do movimento ou de alguma pessoa de suas relações em um dos quartos. O tráfico que invadiu desta vez, relataram os moradores, encarnava a voz do seu novo e atual comando, substituto de Verônica, presa meses antes.

Este evento desolador nos foi relatado por um morador que, ao tentar impor a sua autoridade como militante e referência na cena das ocupações do centro - aqui é nossa casa, a ocupação é nossa e, portanto, mandamos nós - ganhou como resposta uma reação violenta do jovem que guardava a portaria. Seguiram-se xingamentos e ameaças de espancamento e morte que 
obrigaram este morador a se retirar do prédio. Após estas sérias ameaças, decidiu dar um tempo da ocupação, abrigando-se fora dali.

Foram várias as reuniões dos moradores com militantes e apoios que procuravam impedir o desmoronamento da Nelson Mandela como pilar e legenda de um projeto político e social. Pautaram seus procedimentos com vistas a evitar o pior, a saber: que o domínio do tráfico se apresentasse como irreversível, eliminando as formas de decisão coletiva em prol de um modo de controle violento e autoritário. Os muitos moradores, na falta de alternativa, foram obrigados a acatar a ordem de andar cabisbaixos no interior do imóvel, sujeitando-se ao controle do chefe e às suas ordens, sob a mira de um revólver. A presença do tráfico teve como efeito imediato o enfraquecimento da causa de tantos anos e a possibilidade real de perderem o controle do prédio. Mesmo que uma parte significativa de seus moradores permanecesse no imóvel, a causa dos sem-teto sofrera um forte golpe.

Em discussões acaloradas, nas quais buscavam definir estratégias para a retomada do imóvel, algumas sugestões surgiam para serem logo descartadas. Uma delas foi a volta dos militantes ao imóvel, reocupando-o na marra, proposta abandonada em pouco tempo. Também se pensou em denunciar, através da mídia e das redes sociais, o que se passava. Esta alternativa foi longamente discutida, para ser em seguida abandonada. Uma ação de denúncia provocaria um movimento de retaliação do tráfico contra todos ali dentro. É preciso ressaltar que estava longe do horizonte comum a possibilidade de registrar uma queixa na delegacia próxima, visto que a polícia já tinha se mostrado conivente com o que se passava praticamente na sua porta.

É certo que a luta para conseguir na Justiça a posse do imóvel mobilizou uma parcela significativa dos moradores durante muitos anos. Eles contaram, por sua vez, com o suporte de uma vasta rede de apoiadores, cujas atividades, no entanto, dependiam da liberdade usufruída ali dentro. Ao lermos o processo judicial referente à ocupação, notamos que, desde o momento de entrada até a tomada pelo tráfico, se multiplicaram os atores que apoiaram a Nelson Mandela

Os vínculos entre moradores e os chamados apoiadores tiveram contornos variados e expandiram a ocupação, dando-lhe um perfil distinto das invasões: era uma comunidade social e moral cuja agência foi pouco a pouco ganhando reconhecimento público na cidade, dignificando a causa dos sem-teto e obtendo certa legitimidade. O desenrolar favorável à causa (Lacerda 2012) nos anos 2000 devia-se também ao fato de os militantes e os ocupantes buscarem meios para viabilizar tais projetos, defendidos como estratégias para uma mobilização popular em defesa dos sem-teto. Esses 
ativistas pertenciam a diferentes grupos sociais - estudantes universitários, trabalhadores formais e informais, quadros técnicos da burocracia estatal - e mantinham vínculos políticos com agrupamentos de esquerda, movimentos sindicais, movimentos dos sem-terra e sem-teto e apoio de alguns militantes partidários e/ou anarquistas.

Reiteramos, pois, que a Nelson Mandela não mobilizava somente os seus moradores. Estes estavam inseridos em uma trama de relações que dava eficácia e legitimidade à luta pelo direito à cidade daqueles considerados indesejáveis, no plano jurídico e político em diferentes âmbitos do Estado. Os moradores que se misturavam a essas redes de apoio tinham suas falas e intervenções públicas amplificadas. Note-se que em alguns momentos a causa desses sem-teto alcançou audiência fora do país. Visitas a países europeus, contatos com redes internacionais, ligações permanentes com grupos de universitários e de artistas amplificaram a sua voz e a de seus defensores. Os ocupantes auferiam assim de diferentes recursos sociais, paulatinamente construídos e permanentemente integrados em um cotidiano marcado pela indeterminação e pela precariedade..$^{19}$

A Nelson Mandela atraiu, em suma, estudantes, grupos de teatro, de capoeira, ativistas ligados à área de cinema, à área religiosa, a atividades artísticas, pedagógicas e de assistência infantil, entre outras. A sala de encontros da Ocupação serviu para festas, filmes, animações culturais de todos os tipos, além de ser o lugar das assembleias. Em 2009, podemos ler em seu processo judicial que uma empresa de arquitetura ligada a uma universidade pública apoiava a causa dos sem-teto e ganhara a licitação da reforma do prédio, cuja verba pertencia ao Programa FNHIS (Fundo Nacional de Habitação de Interesse Social). Para nosso espanto, o contrato fora assinado em fevereiro de 2009 pelo governo estadual e dava direito a um financiamento da Caixa Econômica Federal. Assim, apesar dos impedimentos burocráticos e da lentidão dos procedimentos, tudo parecia favorecer a Nelson Mandela.

A ocupação, ou melhor, as ocupações, foram engendradas pela ação de seus militantes e de suas redes como uma causa política no espaço público do Rio de Janeiro e no âmbito das lutas relacionadas ao direito à cidade e à moradia (que ganharam visibilidade principalmente após a Constituição de 1988, em cidades como Curitiba e Porto Alegre e, depois, no primeiro mandato de Luiz Inácio Lula da Silva ${ }^{20}$ ). É importante considerar que o caráter público mais evidente da causa dos moradores se apresenta através do que classicamente é considerado um movimento social, cujos modos de ação, objetivos políticos e formas de presença remetem a tradições já consolidadas na literatura sociológica. No entanto, observamos que, para além desse repertório conhecido, os moradores acionam meios apreendidos 
no viver na viração para efetivar o acesso à cidade. Em outras palavras, utilizam todas as brechas possíveis para garantir, menos como um direito e mais como um modo de existência, o acesso a equipamentos e a recursos urbanos que a vida numa metrópole dispõe. ${ }^{21}$

\section{Contextos mutantes}

A Nelson Mandela teve início em um contexto governamental relativamente favorável às ocupações, principalmente em âmbito federal, no traçado da "grande política" direcionada às demandas populares. No ano de 2003, Luiz Inácio Lula da Silva deu início ao seu primeiro mandato. Em sua campanha, Lula acenou com a promessa de que os prédios públicos abandonados seriam transformados em moradia popular. Entre 2004 e 2011, o ITERJ, Instituto de Terras do Rio de Janeiro, contava com funcionários que se orientavam por uma política de ampliação de direitos no setor de habitação popular. Apoiavam-se também nas promessas do governo Lula para legitimar suas demandas. Os atores deste órgão público do Estado conseguiram junto ao Ministério das Cidades a aprovação de seu pleito de requalificação do imóvel e de financiamento pela Caixa Econômica Federal de forma a atender às demandas de habitação das famílias hipossuficientes ${ }^{22}$ moradoras da ocupação. Frisemos que o antigo centro não tinha ainda se transformado em alvo dos projetos imobiliários e de especulação financeira de grande porte, o que veio a acontecer a partir de $2009 .^{23}$

Em setembro de 2012, momento em que outras ocupações já tinham sido desativadas, a Nelson Mandela conseguiu o uso do imóvel para fins de habitação social. Este reconhecimento jurídico aconteceu após a publicação dos nomes dos moradores, acompanhados do número de seus respectivos apartamentos. Todavia, alguns meses após a sua legalização, o tráfico invadiu o prédio para nele se instalar.

O pequeno intervalo entre o ganho e o usufruto do imóvel e a perda das garantias mínimas para a sua utilização nos causou perplexidade. Afinal, agora que os moradores tinham uma situação regularizada, como era possível que o tráfico entrasse no prédio, acabando por tomar conta do lugar sem que se pudesse fazer nada? Entender a suposta discrepância entre a legalidade atribuída à ocupação e a situação de indeterminação que mantinha seus moradores nas margens ${ }^{24}$ nos instigou desde então. Em outras palavras, a legalização da ocupação não encerrou as ameaças e o caráter precário deste tipo de moradia, e tampouco as formas estabelecidas de ilegibilidade e de gestão diferencial dos ilegalismos, como mencionamos. 
Com efeito, a presença de indivíduos armados na portaria, as ameaças e o palavrório intimidador e humilhante dirigido aos moradores tornaram-se corriqueiros. O recolhimento de lixo melhorou — quem ousava desobedecer ao tráfico? Mas esse pequeno benefício, decorrente da imposição de ordem, não era suficiente para aceitar a dominância de uma micropolítica que aterrorizava os moradores. Embora não tenham ficado sozinhos, viram-se, de alguma forma, conforme suas palavras, abandonados. As redes que podiam acionar no passado recente não respondiam mais, além disso, já estava clara uma amplificação dos problemas locais por intermédio dos projetos do Porto Maravilha: aumento dos aluguéis do entorno, ameaças de violência, remoções em morros vizinhos, diminuição de ofertas no mercado de trabalho local e a restrição das atividades de camelôs e ambulantes na área.

Para responder à nossa perplexidade sobre a entrada do tráfico no prédio da Nelson Mandela, tornou-se necessário entender melhor o quadro dos acontecimentos que solapavam a permanência de populares na região. Segue agora a apresentação de uma pequena cronologia — uma listagem de acontecimentos significativos que contribuíram para esse estado de coisas:

a) em fevereiro de 2009, três sobrados (invasões populares) pegaram fogo e seus moradores foram desalojados; um número significativo deles se transferiu para o prédio de uma outra ocupação na região portuária, que passou a sofrer de superlotação, o que contribuiu para desestruturar os modos de convivência no interior deste coletivo também autogestionário. A ocupação seria desde então avaliada pela maior parte dos antigos ocupantes como "infernal" e "caótica";

b) em outubro de 2009, houve o anúncio dos Jogos Olímpicos e, consequentemente, o deslanche do projeto Porto Maravilha;

c) em 2010, foi exonerada a equipe considerada progressista no Ministério das Cidades (Olívio Dutra e Raquel Rolnik, entre outros), o que diminuiu o apoio do governo federal aos projetos de moradia popular na região;

d) em abril de 2010, foi inaugurada a UPP do morro da Providência; em seguida, diversos traficantes se transferiram para casarões da região, inclusive para as ocupações;

e) em abril de 2010, aconteceu um incêndio no Camelódromo, situado ao lado da Central do Brasil, que devastou todos os boxes, desalojou os ambulantes e gerou efeitos severos sobre a economia local;

f) em junho de 2010, o BOPE (Batalhão de Operações Especiais da Polícia Militar do Estado do Rio de Janeiro) invadiu uma das ocupações próximas à ocupação Nelson Mandela sob a justificativa de procurar traficantes que teriam descido de um morro adjacente; logo depois, agentes do tráfico se instalaram nessa ocupação e passaram a gerir seu espaço; 
g) em janeiro de 2011, os moradores de outra ocupação foram instados a abandonar o prédio sob pressão e chantagem da prefeitura, que ofereceu aluguel social, dinheiro ou apartamento na zona oeste; ${ }^{25}$

h) em abril de 2011, o então governador do estado, Sérgio Cabral, desmantelou o grupo estruturado no Núcleo de Terras/ITERJ que dava suporte aos movimentos de moradia popular; ${ }^{26}$

i) em junho de 2011, o Consórcio de Empresas Privadas do Porto Maravilha (CEDURP) foi criado para gerir as operações financeiras relativas aos terrenos cedidos pelos governos federal, estadual e municipal e administrar os serviços outrora públicos da área;

j) em 2011, casas localizadas no morro da Providência começaram a ser marcadas com a sigla SMH por agentes da prefeitura, em referência à Secretaria Municipal de Habitação, sem aviso prévio, traduzida pelos moradores como Saia do Morro Hoje;

k) em 2012, uma das ocupações foi invadida por egressos dos casarões incendiados e das ocupações esvaziadas, com o assentimento e o controle do tráfico;

l) em 2013, a grande mídia veicula que em uma das ocupações seriam erguidas até 10 Torres Trump; ${ }^{27}$

m) no carnaval de 2014, outra ocupação foi esvaziada e as garantias de realojamento acordadas pela prefeitura não foram cumpridas.

Note-se que, nesse brevíssimo inventário, o conjunto de eventos provocou efeitos sucessivos em muitos domínios entrelaçados - particularmente aqueles referentes ao trabalho informal e às moradias precárias - que em parte garantem a densidade econômica e social deste vasto mercado de transações de todos os tipos, formais e informais. Foram efeitos em cascata engendrados por cinco ordens de eventos: incêndios, expulsões pela prefeitura, derrubada de imóveis, remoções e crescimento da força do tráfico e de seu poder de controle no asfalto. Como não é difícil de imaginar, tais eventos não atingiram todos da mesma maneira.

Para o projeto urbano previsto, a gestão dos ilegalismos se fazia no sentido de não permitir o restabelecimento dos arranjos e das transações que ali ocorriam e que vivificavam o comércio gerador de renda e de trabalho, responsável em parte pela densidade do local em termos de sociabilidades as mais variadas. Estes eventos se deram no sentido de diminuir os atrativos dessa parte da cidade, limitando progressivamente os circuitos existentes. No entanto, a face mais violenta dos ilegalismos, aquela usualmente associada ao crime - o tráfico de drogas - foi fortalecida, ao menos no primeiro momento, quando "desceu" do morro para o asfalto, tornando-se, como 
estamos sugerindo, um ator da governamentalidade fundamental no processo de expulsão dos "indesejáveis" da zona portuária, e ganhando, neste contexto, um protagonismo de peso, principalmente ao exercer um poder de controle sobre algumas invasões populares quase invisíveis para os de fora e também nas ocupações engendradas pelos movimentos de sem-teto.

Devastação, destruição, violência e abandono delinearam-se de modo a provocar na paisagem o que os projetos de revitalização já designavam como uma zona vazia da cidade: um lugar sem nada, onde era necessário proporcionar movimento econômico e ocupar o espaço, ${ }^{28}$ atraindo uma nova população para os bairros que iriam surgir (Guimarães 2011).

Enquanto causa política referente ao direito à cidade, os moradores das ocupações e a população do seu entorno defrontaram-se desde o início do projeto Porto Maravilha com uma modalidade de identificação que os responsabiliza pelos problemas que os atingem. Eles seriam os maiores responsáveis pela "desordem endêmica" que institui os modos de vida populares. Logo, os incêndios, o desemprego, as atividades de viração, as remoções, as ameaças, a falta de limpeza urbana, a decadência dos serviços públicos e a precariedade das moradias seriam causadas por eles mesmos. São assim facilmente identificados como a causa dos males que os atingiram em razão de seu caráter moralmente insuficiente. ${ }^{29}$ Em face da modernização prevista, os trabalhadores informais, os supostos bandidos, as prostitutas, os moradores de rua, os ambulantes e os favelados, entre outras categorias, justificariam uma orientação centrada no esvaziamento paulatino da vitalidade própria da região e de seus moradores. A política de gentrificação em curso é também uma biopolítica de deslocamentos populacionais que reordena a cidade e suas fronteiras. ${ }^{30}$

\section{Reconfiguração do tráfico e choque de ordem}

No início de 2013, o comércio de drogas dos morros da região do centro passava por remanejamentos. Novos arranjos aconteciam em outros bairros da cidade depois da instalação das UPPs, em 2008. Verônica, conhecida como a tia do tráfico e famosa por fazer uma gestão do comércio de drogas com mãos de ferro na região da Central do Brasil, havia sido presa pela Polícia Civil do Estado do Rio de Janeiro juntamente com outros líderes, pessoas supostamente envolvidas com comércio ilegal de drogas, além de 21 policiais militares, num total de 72 pessoas detidas.

A prisão de Verônica teve um efeito imediato na Nelson Mandela. Foi após a sua saída do comando do tráfico que a regra implícita de não inter- 
ferência na ocupação deixou de vigorar. Dentre as mudanças, houve uma maior pulverização do negócio das drogas através da ampliação do número de esticas no asfalto. ${ }^{31}$ Se a UPP, ao menos em um primeiro momento, dificultou a permanência do tráfico na favela nos moldes habituais de funcionamento, por outro lado, os policiais militares e civis mantiveram uma "cegueira seletiva" quanto à sua expansão pelas ruas do centro da cidade. As ocupações tornaram-se, dessa feita, alvo direto da disputa por novos lugares que atendessem a um modelo de vendas mais difuso e capilar.

Já para os camelôs e ambulantes da região, os espaços próximos das esticas eram tidos como lugares de relativa segurança, já que mantinham distantes os famigerados guardas municipais (lembremos que no primeiro dia de mandato do prefeito do Rio de Janeiro, Eduardo Paes, em 2008, foi criada por decreto a Secretaria de Ordem Pública, o que complicou sobremaneira o cotidiano de ambulantes e camelôs).

Um ocupante que ganhava a vida com uma carrocinha de hambúrgueres argumentava, justificando sua proteção pela estica, o quanto era difícil obter a regularização de seu pequeno comércio por conta das inúmeras exigências colocadas pela prefeitura que lhe cabia preencher. Com a criação da Secretaria de Ordem Pública, conhecida na cidade como a Secretaria do Choque de Ordem, um enorme contingente de guardas municipais tomou as ruas, aumentando as tensões e as disputas diárias por espaço de vendas no centro. Foi a partir dessa política, que visa à retirada dos "indesejáveis" das ruas, que nosso interlocutor se deu conta do contexto ainda mais duro para os seus negócios.

Antônio já tinha vendido quentinhas em um triciclo para os trabalhadores do centro. A repressão desencadeada na região na época dos Jogos Pan-Americanos inviabilizou seu negócio, haja vista que sua clientela - composta de viradores como ele próprio - foi impedida de trabalhar nesse período. A proximidade com o tráfico, que fechava certas ruas ostensivamente para todo passante desconhecido, garantia a proteção contra os guardas municipais, mas também dificultava as vendas aos clientes, como rapidamente percebeu. Em troca da proteção indireta propiciada pela proximidade dos meninos do tráfico, o nosso interlocutor lhes oferecia hambúrgueres, o que pesava demais no seu orçamento. Ao voltar para a rua "sem proteção", foi obrigado a funcionar somente depois que os guardas municipais se retiravam à noite. A pouca clientela existente no período noturno não o ajudou a evitar a falência.

A presença da guarda municipal, da polícia militar, da UPP e do tráfico engendraram uma atmosfera persecutória e um clima de tensão que tomaram as ruas e os arredores da Central do Brasil. Todas essas transformações envolvendo o projeto político do Porto Maravilha passaram a dificultar os 
ganhos diários desses trabalhadores informais. As ações da polícia, que tinham como alvo o enfraquecimento do poder do tráfico em certos pontos e, com elas, a possibilidade de que novos líderes ou novos "xerifes" despontassem, realçavam essa atmosfera persecutória.

Da mesma forma, a tomada pelo movimento de espaços no prédio, que antes eram utilizados para atividades dos moradores e da militância, tornava-se signo da reconfiguração do tráfico. Ao invadir o prédio, o tráfico passou a operar como parte importante do dispositivo de desmantelamento do projeto político da ocupação, fortemente associado à gestão coletiva e à sua autonomia. Não podemos ignorar que alguns moradores, num primeiro momento, julgaram positiva a chegada do movimento: alcançar a ordem mediante o exercício da obediência sob a força das armas livrava-os do cansaço de uma democracia direta muitas vezes exaustiva. Mas a imposição de pessoas armadas nos locais comuns do imóvel, a posse pela força de alguns quartos, as humilhações correntes, a entrada de usuários de todos os tipos e a perda do controle do prédio pelos moradores provocaram objeções crescentes a essa suposta solução para os conflitos envolvendo a administração e o cuidado do espaço.

\section{Gerentes, advogados, meninos e negociações}

A forma de atuação do tráfico na Nelson Mandela operava com outros arranjos quando Verônica, líder do tráfico na região, exercia a chefia. É interessante mencionar quais seriam esses arranjos para desfazer um possível mal-entendido. Não queremos apresentar os conflitos entre as pessoas associadas ao tráfico e os moradores da ocupação através de uma percepção que os colocaria em mundos separados e excludentes entre si. Já mencionamos formas de transversalidade existentes entre esses domínios por meio de relações familiares, de trabalho e de vizinhança. Vamos agora descrever através do prisma das negociações os movimentos que os moradores fizeram para impedir ou interromper as investidas dos meninos do tráfico, do gerente e do advogado do grupo do tráfico na ocupação antes da tomada efetiva do imóvel.

Uma primeira situação que nos foi contada refere-se a uma moradora da ocupação, de temperamento explosivo. Ela tentou roubar para si o quarto de seu vizinho que estava hospitalizado. Os militantes intervieram e se defrontaram com a sua ameaça de acionar o tráfico. Em nome de relações passadas com o movimento, ela procurou se impor por meio de ameaças de coação. Militantes e moradores da ocupação se viram, em certo momento 
dessa disputa, instados a realizar uma reunião dentro do prédio com o advogado do tráfico. Ele discutiria o caso e tentaria resolvê-lo, assumindo o papel de mediador. Mesmo que a presença do advogado desagradasse aos moradores, eles contemporizaram, concordando com sua presença. O advogado, então, aceitou os argumentos dos moradores e, com o apoio destes, forçou a invasora do quarto alheio a desistir do seu intento.

Outra tentativa de invasão ocorreu quando um grupo de meninos do movimento entrou em um quarto momentaneamente vazio para levar namoradas e realizar festas no apartamento. Nessa ocasião, a solução foi contatar Verônica, a líder do tráfico naquele momento, enviando-lhe uma carta, na qual solicitavam o seu apoio à causa dos moradores. A missiva conseguiu chegar às mãos da Verônica por conta de uma mãe que havia perdido os filhos no chamado caso da Providência e que, na época do assassinato de seus filhos, recebera apoio de um grupo de direitos humanos ligados também à cena das ocupações do centro. E foi assim que obtiveram a recuperação do quarto, garantida pela hierarquia do grupo de tráfico na região e pela rede de apoiadores das ocupações. ${ }^{32}$

Uma nova invasão aconteceu depois da prisão de Verônica. Agora a possibilidade de acionar os líderes do tráfico não existia mais, porque, afinal de contas, fora o novo gerente quem pessoalmente instalara uma boca de fumo no imóvel. Após três meses como gerente da boca, ele terminou assassinado pelos policiais da UPP da Providência. Outro entrou e, depois, ainda mais dois, um pouco menos violentos — segundo uma moradora mas igualmente armados.

A suposição de que o recurso à polícia poderia se voltar contra os militantes e os moradores baseava-se na natureza do contrato de uso do imóvel assinado por todos e intermediado pela Defensoria Pública. É preciso repetir que a ocupação Nelson Mandela garantiu o uso legal do imóvel, entretanto, ele poderia ser revogado pela União ou pelo governo do estado sem qualquer indenização se fosse utilizado para práticas consideradas ilegais. Um novo dispositivo se exercia: a ilegalidade do tráfico não suspendera a exigência de moralidade e de controle disciplinar. É a associação entre possíveis acusações de ilegalidades e de criminalização dos moradores que faz com que a conexão entre tráfico armado, polícias militar e civil e agentes do estado continue ameaçando, em termos legais, a ocupação.

O quadro menos violento e agressivo instituído pelo gerente mais recente possibilitou a volta de alguns moradores a seus apartamentos. O que estamos designando como menos violento pode ser compreendido também como uma aceitação aparente por parte dos moradores do controle disciplinar que se impôs ali. As tentativas de recuperar a autonomia da ocupação, no en- 
tanto, não deixaram de ser aventadas. Os moradores mais ativos reiniciaram seus contatos com algumas pessoas ligadas às antigas redes de apoio. Sob o incitamento dos mais animados, Janete buscou recuperar do processo de legalização do imóvel a promessa de requalificação do prédio disponibilizada pelo FNHIS. Além disso, outros moradores empenharam-se em reanimar os encontros que ocorriam no salão de reuniões da Nelson Mandela.

A primeira tentativa fracassou diante do medo que sentiu o grupo de artistas que faria um pequeno espetáculo ali dentro. Eles não ousaram entrar ao serem recebidos por pessoas armadas na porta. Em outra frente, havia interesse de parte significativa dos moradores de conseguir instalar telefone fixo e também de obter acesso à internet banda larga. Os técnicos que instalariam o acesso, contudo, foram barrados pelos meninos do tráfico na porta. Visitas ao prédio escassearam. A tensão é inevitável quando se é identificado na porta para ultrapassar a fronteira armada. Uma convivência e uma conivência, ambas silenciosas e tensas, se instituíram entre esta nova estica e as intervenções relativas ao Porto Maravilha.

Após algumas semanas da invasão pelo tráfico, ocorreu uma festa rave com dois dias de duração, evento emblemático que marcou a entrada dos novos gestores do lugar. A festa, ocorrida no primeiro semestre de 2013, conforme nos contaram alguns moradores, teve toda a bandidagem da região ligada ao grupo de narcotráfico dominante na área convidada. Muitas pessoas passaram pela festa, na qual o grupo de traficantes oferecia cerveja gratuita com a segurança garantida por policiais que, em dois carros, faziam vigília na porta.

Essa festa tornou público para a vizinhança quem era agora o dono do imóvel e o novo gerente do tráfico da região. Também ficou claro para todos que os novos invasores contavam, naquele momento preciso, com o apoio das forças da ordem presentes no bairro. O líder do grupo bradou algumas vezes que gostava de bater em mulher. Ainda nessas semanas de início da invasão, uma garota foi objeto de uma ação violenta do tráfico: o gerente do movimento amarrou suas mãos e pernas e passou a moto por cima de sua barriga, acusando-a de cracuda e de lhe dever dinheiro. O controle do tráfico sobre o imóvel se apresentava como parte do emaranhado que tornava quase impossível uma ação dos moradores capaz de o expulsar dali. Por um lado, temia-se a conivência da polícia, por outro, a vingança do tráfico, caso a polícia agisse. E ainda, para completar, o imobilismo forçado era compreendido por setores do Estado como uma falta dos próprios moradores, que inviabilizava o financiamento para as melhorias do prédio já prometidas, por permitirem a presença do tráfico. Reproduzimos como uma de nós relatou esta situação em seu caderno de campo: 
Uma das tentativas desesperadas de Carmen para sair da ocupação é conseguir um dos apartamentos no conjunto habitacional Minha Casa Minha Vida, construídos em um bairro circunvizinho. Para tanto, resolve ir ao ITERJ denunciar o que está acontecendo (a invasão e a instalação de uma estica do tráfico na ocupação). Ao chegar, é atendida por uma assistente social. Diferentemente das preocupações de outros militantes e apoios, que tomavam dezenas de cuidados para não expor o assunto e, consequentemente, a ocupação, Carmen solta o verbo e fala o que está se passando. Fala para a secretária, para a assistente social, enfim, para todo mundo que ela vê pela frente (segundo sua narrativa) que tudo lá está um inferno.

Como resposta, a assistente social argumenta: "Já que ela morava em uma habitação de interesse social regularizada pelo Estado, e se agora há o problema do tráfico, não é o ITERJ quem vai resolver". E insiste, dizendo: "O problema do tráfico é dos moradores que deixaram o tráfico entrar". As respostas foram deixando Carmen cada vez mais nervosa, afinal, este era exatamente o seu argumento, mas feito em um sentido inverso: se o tráfico invadiu a ocupação e não é mais possível morar lá, era óbvio que o Estado tinha que garantir o direito à moradia e, portanto, deveria tirá-las de lá (notemos que não se trata de o Estado retirar o tráfico da ocupação, mas sim de conseguir fazer com que ele [Estado] lhes assegurasse outro tipo de moradia). Após esse choque, Carmen passou a gritar com a assistente, que apontou o dedo para ela e gritou de volta (Fragmento do caderno de campo, início de 2013).

Citemos uma outra situação em mais um fragmento do caderno de campo mencionado:

A rua da ocupação está passando por uma grande reforma nas tubulações de água e esgoto. Agentes da prefeitura trabalham dia e noite nesta empreitada.

Não é a primeira vez que os garotos do tráfico de drogas presentes na Nelson Mandela querem recolocar o portão. É preciso lembrar que foi a polícia civil que o retirou meses atrás. Segundo alguns moradores, isto serviu para facilitar as incursões policiais, mas também teve efeitos para os moradores, que tinham ficado como reféns dos meninos que guardavam a portaria, e agora tinham uma liberdade de trânsito um pouco maior. Ocorre que o portão em funcionamento retardava a entrada dos policiais e facilitava a fuga dos garotos pelos fundos da ocupação. Assim, os garotos do tráfico já assinalavam que voltariam a recolocar o tal portão. (Nesta semana houve uma tentativa concreta do tráfico de fazer isso. A ideia de alguns moradores foi contatar uma ONG conhecida para que esta sugerisse alguma alternativa). Pois bem, os garotos do tráfico, depois de tirarem a medida, compraram um portão e pa- 
garam aos agentes contratados pela prefeitura para que o instalassem (esses agentes foram contratados através do consórcio público privado Porto Novo, que trabalham na reforma da tubulação da rua). Alguém resolveu denunciar numa delegacia próxima a presença do tráfico e os transtornos que o grupo de garotos estava causando ao prédio. A polícia, após a denúncia, teria vindo e levado o portão embora. Mas antes me foi relatada a seguinte conversa: [Policial:] "Quem mandou vocês colocarem esse portão?", [Agente do Consórcio Porto Novo:] "Ah, foi o morador?", [Policial:] "Como? Se teve morador que foi fazer denúncia desse portão... Morador não quer esse portão não!". Conclusão: a polícia levou mesmo o portão embora. Os garotos do tráfico ficaram sabendo que um morador havia feito a denúncia, e passaram a gritar pelos corredores ameaças aos moradores: "Se a gente pegar quem dedurou, a gente mata", e "X9 tem que morrer".

Temos aqui nestas situações a soma de poderes da polícia, do tráfico e também da administração do estado relacionada à política da reurbanização, que é inseparável da violência, como estes fragmentos demonstram.

É muito difícil narrar os obstáculos e os sofrimentos vividos pelos moradores dessa região sem sermos tomadas por um sentimento tanto de indignação quanto de impotência. As formas de intimidação eram exercidas de maneira a não deixar dúvidas quanto à inexistência de limites à violência que eles poderiam sofrer. A violência corporal tinha algo de encenado também: os silêncios dos moradores eram desafiados por gritos intimidativos. As tentativas discretas de resistência podiam desencadear ataques verbais e corporais e mesmo a expulsão da moradia. A violência parece sempre parte de uma encenação cujo caráter amedrontador tem uma finalidade pedagógica: o reconhecimento do poder do gerente de punir ou matar aqueles que ele submete. Cenas de tortura nos foram relatadas: pessoas enroladas como se mumificadas, batidas e surradas. Correm rumores de que algumas foram assassinadas dentro das ocupações e invasões. Casarões da redondeza teriam se transformado em lugar de desova de cadáveres, transportados em carrinhos de lixo da Comlurb (o que também acontece em favelas no Rio ${ }^{33}$ ). Alguns quartos foram brutalmente tomados pelo movimento que, ao expulsar os moradores, jogou seus pertences pela janela, além de ameaçá-los de morte. Um silêncio atravessado por gritos e outros sons se impôs como algo banal. Nossa narrativa, portanto, é uma tentativa de se contrapor a esse silenciamento, da mesma forma que procura entender o que tem significado, nos dias de hoje, a luta por habitação numa região que se gentrifica com a participação e sob os olhares atentos dos governos estadual, federal e municipal. 


\section{Epílogo}

O Porto Maravilha, o megaprojeto responsável direto pelas transformações do antigo centro da cidade, insere-se em um modelo de cidade que o ultrapassa. Esse modelo, por sua vez, adquiriu forma através de uma longa história do Rio de Janeiro, cuja principal característica é um planejamento da cidade que, desde o século XIX, busca construir o tecido urbano de modo a reduzir a presença e a circulação das classes populares: trabalhadores formais e informais, ambulantes, moradores de rua, camelôs e todos aqueles identificados como pobres, marginais, bandidos, prostitutas, drogados etc. A política atual não difere muito das anteriores deste ponto de vista. Contudo, a força do processo de revitalização não pode ser dissociada do contexto político da cidade do Rio de Janeiro. Buscamos aqui descrever um campo cuja complexidade coloca em evidência uma miríade de fatores que incidiram sobre a população-alvo dessa reforma urbana, principalmente aqueles relacionados ao governo dos pobres e a novas formas de controle e de disciplina que se encontram em curso.

Valorizamos particularmente a atuação do tráfico de drogas como um poderoso instrumento de desestabilização das moradias populares em uma área do asfalto onde ele supostamente não atuaria tão abertamente, controlando o seu comércio nas ruas, ocupando moradias e criando uma atmosfera de terror. Assinalamos que o terror imposto pelo tráfico no asfalto tem feito parte do processo de produção da precariedade e da violência nessa região de moradias populares, e que vem se constituindo, por sua vez, como uma modalidade de governar os pobres que envolve variadas instâncias e atores governamentais e não governamentais. Assassinatos, violência física, desaparecimento de corpos são mencionados como parte desse cotidiano. O perfil urbano de certas áreas já foi transformado.

É interessante perceber como um regime de indeterminação se inscreve e opera nas práticas governamentais que descrevemos. A complexidade dos imbricamentos apontados entre práticas e poderes diversos revela, por um lado, a impossibilidade de separar Estado e sociedade, como apontamos, e por outro, mostra, através de certas linhas de força, processos de negociação que se fazem presentes através de uma grande desigualdade de recursos e poderes envolvidos nessa reurbanização. Mesmo que se tenha alcançado judicialmente direito de acesso à cidade para certos grupos populares envolvidos com as ocupações, esse acesso não suspendeu o regime de indeterminação ao qual esses atores se encontram inseridos também em função do quadro da reurbanização da cidade. Bem pelo contrário, ele intensificou a gestão diferencial dos ilegalismos pelo peso que adquiriu o 
tráfico de drogas, juntamente com a ilegibilidade que tem caracterizado as políticas e ações da governamentalidade sobre as formas de vida e de trabalho na região.

Recebido em 14 de julho de 2014

Aprovado em 16 de novembro de 2014

Patrícia Birman é professora da UERJ e pesquisadora do CNPq. E-mail: $<$ patriciabirman@gmail.com>

Adriana Fernandes é pós-doutoranda no PPCIS/UERJ e bolsista Capes/Faperj. E-mail: <dricafernandes@yahoo.com.br>

Camila Pierobon é doutoranda em Ciências Sociais pelo PPCIS/UERJ e bolsista CNPq. E-mail: <camilapierobon@gmail.com>

\section{Notas}

${ }^{1}$ A ocupação Nelson Mandela faz parte do circuito de ocupações autogestionárias surgidas nos anos 2000. Ao todo foram cinco ocupações situadas nas proximidades da Estação Ferroviária Central do Brasil que funcionavam através de assembleias horizontalizadas e não representativas. As áreas e os imóveis invadidos eram originalmente patrimônio estatal (federal ou municipal) e encontravam-se vazios. Um grupo que se autodenominava operativo viabilizou a ocupação, descobrindo prédios ociosos passíveis de serem invadidos, e articularam o contato com a Defensoria Pública e com uma rede de apoiadores (advogados, movimentos sociais e estudantes/ professores universitários). No caso da ocupação da qual trataremos, o número de moradores variava entre 150 e 200 pessoas. Os nomes da ocupação mencionada e dos personagens que aparecem no texto são fictícios.

${ }^{2} \mathrm{O}$ termo ocupação, diferente de invasão, refere-se a uma forma de moradia coletiva organizada através de uma perspectiva política que supõe o direito dos moradores de obterem o acesso a casa, apropriando-se de imóveis abandonados, gerindo-os como parte de uma luta coletiva por moradia. Assim, a ocupação não teria donos, mas militantes comprometidos com um modelo autogestionário da coletividade que se estabelece. O "tráfico", ao "invadir", busca estabelecer um poder de mando e um controle sobre os moradores, desfazendo, portanto, a ordem comum existente. 
${ }^{3}$ Vários dossiês foram produzidos pelos chamados Comitês Populares da Copa no âmbito das capitais que receberam os jogos. Sobre o teor das intervenções realizadas no Rio de Janeiro, remetemos ao $3^{\circ}$ Dossiê Megaeventos e Violações de Direitos Humanos, lançado em junho de 2014: http://global.org.br/programas/edicao-2014-do-dossie-megaeventos-e-violacoes-de-direitos-humanos-e-lancada-no-rio-de-janeiro/

${ }^{4}$ Como formulado em Birman, Leite, Machado e Sá Carneiro (2014), "Trata-se de abandonar, como sugeriram Veena Das e Deborah Poole (2004), a dicotomia entre Estado e sociedade, herança da perspectiva weberiana que valoriza a sua soberania, com base em uma ordem racional-legal que constitui o fundamento da obrigação política, fazendo da "sociedade" o lugar da falta, exemplo maior do que "ainda" não conseguiu impor. Assim se estabelece uma visão binária que faz da sociedade o lugar por excelência da indisciplina e da desordem, da anomia, e da incivilidade, e faz do Estado a instituição que, do "centro", buscaria combater a desordem, ao se espraiar por suas periferias, impor a sua racionalidade, garantir o cumprimento da lei e da ordem".

${ }^{5}$ Seguindo as pistas de Giorgio Agamben, e de forma muito resumida, por indeterminação, ele entende situações em que as fronteiras entre a lei e a não lei são incertas. Nas palavras do filósofo: "O sistema político não ordena mais formas de vida e normas jurídicas em um espaço determinado, mas contém em seu interior uma localização deslocante que o excede, na qual toda forma de vida e toda norma podem virtualmente ser capturadas" (Agamben 2004:182).

${ }^{6}$ Como considerou Birman (2014): "A delinquência, segundo os exemplos históricos de Foucault (2009 [1975]) (também valorizados por Telles (2010), é um efeito da penalidade da detenção. Diz ele [...] é uma ilegalidade que o 'sistema carcerário', com todas as suas ramificações, investiu, recortou, penetrou, organizou, fechou num meio definido e ao qual deu um papel instrumental em relação a outras ilegalidades. Em resumo, se a oposição jurídica ocorre entre a legalidade e a prática ilegal, a oposição estratégica ocorre entre as ilegalidades e a delinquência"; "Os tráficos de armas, os de álcool nos países de lei seca, ou mais recentemente os de droga, mostrariam da mesma maneira esse funcionamento da 'delinquência útil'; a existência de uma proibição legal cria em torno dela um campo de práticas ilegais, sobre a qual se chega a exercer um controle e a tirar um lucro ilícito por meio de elementos ilegais, mas tornados manejáveis por sua organização em delinquência. Este é um instrumento para gerir as ilegalidades. Pode-se dizer que a delinquência, solidificada por um sistema penal centrado sobre a prisão, representa um desvio de ilegalidade para os circuitos de lucro e de poder ilícitos da classe dominante" (Foucault 2009 [1975]:265). Creio que este ponto de vista pode nos ser útil, porque nos permite, ao mesmo tempo, separar e pôr em relação a delinquência como organização relacionada ao sistema carcerário - aquela analisada por Biondi (2010) - por exemplo, a pequena delinquência que atravessa os ilegalismos populares (Telles 2010; Feltran 2007).

${ }^{7}$ Sobre a construção da Secretaria de Ordem Pública e as atuações do "Choque de Ordem" na cidade, ver: Nacif, Cardoso e Ribeiro 2011; Santos 2012; Hirata 2014. 
${ }^{8}$ Na reportagem publicada pelo jornal O Globo, "Revitalização da Zona Portuária impulsiona mercado imobiliário", destaca-se o reajuste de até $500 \%$, em uma década, do valor do metro quadrado na região: http://oglobo.globo.com/rio/revitalizacao-da-zona-portuaria-impulsiona-mercado-imobiliario-5090451. Acesso em: 20/07/2012.

${ }^{9}$ Em sua análise sobre o modelo Barcelona de reforma urbana, Delgado (2007) aponta três procedimentos a serem executados a fim de se alcançar uma reforma "vitoriosa". Grosso modo, os procedimentos são: 1. escolher um bairro histórico e obsoleto, elaborar sobre ele um plano perfeito, prometer uma existência melhor para as pessoas, que será remodelada junto com a localidade, engendrar um regime de lógica público-privada e transparente; 2. estabelecer ofertas de realojamento para aqueles que não podem assumir as condições impostas, organizar formas de participação orientadas para dividir os moradores afetados e, concomitantemente, continuar submetendo este espaço da cidade a um processo de deteriorização para dissuadir as "vítimas-beneficiárias" da transformação urgente e inevitável; 3. aplicar formas de mobbing institucional, a saber, uma técnica de assédio e demolição que consiste em fazer a vida impossível para os habitantes que se negam a abandonar casas condenadas pelos planos urbanísticos e imobiliários, submetendo-os a uma pressão que os obrigue a abandonar sua resistência e deixar o espaço livre para a revitalização do bairro (Delgado 2007:46). Há de se destacar que o projeto Porto Maravilha foi inspirado no modelo Barcelona e a parceria de cooperação Rio-Barcelona foi assinada em 2009 e reafirmada em abril de 2014. Ver: http://portomaravilha.com.br/materias/ prefeito-barcelona-visita/p-b-v.aspx. Acesso em: 06/07/2014.

10 "Tráfico" aqui é uma categoria que empregaremos destacando os usos locais e as referências conforme circulam e ganham relevo. Concordamos com a observação de Antonio Rafael Barbosa de que "Não existe um único tráfico de drogas no Rio de Janeiro. E podemos supor que tal constatação serve, com algumas exceções, para toda cidade média ou grande cidade, no Brasil ou fora dele. A noção de rede é de grande valia aqui. O que temos é um emaranhado sem fim de redes sobrepostas a outras redes. [...] Certamente, entre essas redes existem os mais diferentes pontos de contato e, para tornar as coisas ainda mais complicadas, cada uma delas é nitidamente segmentada. São diversos os segmentos que operam no atacado, assim como no comércio varejista da droga, para cada caso" (Barbosa 2006:121).

${ }^{11}$ Na página virtual do Porto Maravilha há uma série de enunciados que sinalizam o teor do projeto: "[...] um sonho que virou realidade", um mote repetido à exaustão de que a cidade será "reformulada", com o investimento na ideia de um projeto tão magnífico que nem precisariam ser discutidos publicamente os seus detalhes. O site, com vídeos da imagem da futura cidade "reformulada", é ilustrado também com fotografias das maquetes de monumentos de grande porte que serão erguidos. Segue a descrição: "O Porto Maravilha é uma Operação Urbana que prevê o reencontro da Região Portuária com a cidade". Afinal, é uma região "[...] esvaziada, abandonada e degradada". O Porto Maravilha "devolveria" ao Rio um "tesouro histórico" e espaços com grande "potencial habitacional, cultural e econômico que se transformarão em exemplo de modernidade". E ainda: "[...] é o de fazer da região 
uma das áreas mais atrativas da cidade". Em 2011, num seminário sobre o Porto Maravilha no IHGB, o vice-prefeito Carlos Muniz observou que, para realizar a dita "reforma", seria necessário fazer a "realocação" de uma quantidade de pessoas que não serviriam ao propósito do projeto: "[...] eu queria dizer o seguinte, essa defesa de que não se pode mexer em nenhuma área em que exista população morando da forma mais degradante é uma defesa [...] no fundo, do maior imobilismo político-social. [...] Para que se urbanizem determinadas áreas da cidade, é fundamental que a gente realoque determinadas pessoas". Segundo ele, depois dessas ações, esta parte do Rio seria finalmente "integrada" às áreas que têm "vida" na cidade.

${ }^{12}$ A título de exemplo, nesta reportagem de 2013, a Zona Portuária aparece como "subaproveitada" e "abandonada": http://oglobo.globo.com/opiniao/a-revitalizacao-que-passa-pela-zona-portuaria-10260566. Acesso em: 06/10/2013.

${ }^{13}$ Conforme nos explicaram os pesquisadores Cristina Nacif, Diego Cardoso e Maria Ribeiro: “a Secretaria Especial de Ordem Pública, a SEOP, foi criada a partir do decreto $\mathrm{n}^{\circ} 30.339$, no primeiro dia do mandato de Paes, em primeiro de janeiro de 2009, "sem qualquer consulta ao Legislativo ou participação popular", em caráter "especial", ou seja, 'pretensamente transitório'". "Constituem a secretaria órgãos já preexistentes na estrutura municipal, mas que tradicionalmente atuavam com autonomia e isolamento, a saber: Subsecretaria de Fiscalização (incorporação da Companhia de Licenciamento e Fiscalização - CLF e Companhia de Fiscalização de Estacionamento e Reboque - CFER), de controle urbano (incorporação do órgão Companhia de Controle Urbano - CCU) e de operações (Guarda Municipal)" (2011:10).

${ }^{14}$ Segundo os mesmos autores, tal Plano se insere nos chamados Planos Estratégicos que, no mandato de Eduardo Paes, estariam orientando "as ações do poder público de maneira muito mais concreta" (2011:11). Da mesma forma que: "A formulação desses planos é bem vista e inclusive incentivada pelas agências multilaterais, como um status de integração e competitividade, gerando, assim, captação de grandes fomentos e de eventos mundiais como os esportivos" (:13). E ainda, o plano estratégico relativo ao Choque de Ordem, de 2010, teria sido construído por técnicos da então recentíssima SEOP, sem qualquer tipo de consulta aos grupos diretamente envolvidos (camelôs, ambulantes, população de rua, flanelinhas, usuários de drogas, entre outros), nem às respectivas Associações ou Conselhos de Saúde e de Assistência Social.

${ }^{15}$ No relato apresentado à ONU pela Justiça Global, Rede contra a Violência, Grupo Tortura Nunca Mais, Instituto dos Defensores de Direitos Humanos e pelo deputado Marcelo Freixo, os militares do Exército teriam entregue três "presentes" três jovens moradores do morro da Providência, controlado pelo Comando Vermelho - para traficantes do morro da Mineira, controlado pelos Amigos dos Amigos, facção rival do CV: http://www.redecontraviolencia.org/Documentos/359.html Acesso em: 30/09/2012.

${ }^{16}$ A implantação da UPP no morro da Providência foi acompanhada por uma vasta cobertura midiática que destacou a pacificação do lugar através de reportagens 
em que se viam policiais militares participando de festas promovidas pela Secretaria de Segurança. Festa de 15 anos para jovens da comunidade indicariam uma nova era no morro, consubstanciada pela pacificação social e moral de seus moradores. Ver: http://g1.globo.com/rio-de-janeiro/noticia/2010/08/debutantes-do-morro-da-providencia-vao-ter-baile-com-policiais-da-upp.html. Acesso em: 14/08/2010. Cf. Oliveira (2014) sobre alguns percursos históricos da categoria pacificação.

${ }^{17}$ O termo, tal como compreendido por Michel Foucault (2008), compreende agentes e instituições do Estado, assim como esferas e atores com influência em determinada situação ou contexto: Estado e poder (ou poderes) não se configuram para Foucault, portanto, como esferas unívocas, estáveis, fechadas, mas estão sempre permeadas por disputas, reconfigurações, negociações e rompimentos. A governamentalidade não é setorizada ou classista, embora tais recortes possam ser ativos nesta composição. Seguindo o "método genealógico", a noção pretende "[...] destacar as relações de poder da instituição, a fim de analisá-las [ao partir do prisma] das tecnologias, destacá-las também da função, para retomá-las numa análise estratégica e destacá-las do privilégio do objeto, a fim de procurar ressituá-las do ponto de vista da constituição dos campos [campos de verdade], domínios e objetos de saber" (Foucault 2008:159).

${ }^{18}$ Apoiadores tem sido o termo empregado para designar aqueles que fazem parte das ocupações e se encarregam também de assegurar o seu cotidiano como militantes e não (ou não somente) como os que precisam de moradia (Fernandes 2013).

${ }^{19}$ Cf. Fernandes (2013) descreve minuciosamente situações que ela identifica como próprias de um modo de vida atravessado pela precariedade e por formas de viração.

${ }^{20}$ Para um balanço sobre esta experiência, ver Rolnik (2009).

${ }^{21}$ Trata-se de formas com que certas populações se impõem nas cidades - com que buscam se fixar apesar de tudo, sem necessariamente adotar a linguagem e os repertórios dos movimentos sociais "tradicionais". Podemos remeter aos deslocamentos de migrantes na Europa e na África, como analisa Michel Agier (2008).

${ }^{22} \mathrm{O}$ termo famílias hipossuficientes consta dos processos judiciais referentes às ocupações da área central.

${ }^{23}$ A requalificação da zona portuária já tinha sido aventada durante o mandato de César Maia na Prefeitura, em um projeto nomeado Porto do Rio. Em 2002, no âmbito deste, anunciou-se a construção de um Museu Guggenheim, mas a empreitada sofreu pressões sociais e acabou inviabilizada juridicamente. O Porto do Rio incluía uma ampla "revitalização" da av. Rodrigues Alves e de seus armazéns, entre outras intervenções. Efetivamente, o que se construiu e permanece funcionando: a Vila Olímpica da Gamboa, de 2005, e a Cidade do Samba, de 2006 (Guimarães 2011:20).

${ }^{24}$ Ver Das e Poole (2004). 
${ }^{25}$ Desde 2008, Raquel Rolnik tomou posse na Relatoria da ONU/Habitat, o que significou dotar de maior visibilidade as denúncias quanto à ilegalidade das ações da Prefeitura do Rio em áreas da cidade valorizadas tanto em termos de potencial econômico e empreendimentos corporativos quanto para fins residenciais (espigões para classe média).

${ }^{26}$ Sobre o processo de desmantelamento do Núcleo de Terras/ITERJ, ver Britto e Mendes (2011) e Magalhães (2013).

${ }^{27} \mathrm{O}$ projeto de construção das Torres Trump, conforme anunciado, prevê cinco prédios de 38 andares, com 150 metros de altura cada, num terreno de $32 \mathrm{mil} \mathrm{m}^{2}$. Neste terreno existiu a Ocupação Quilombo das Guerreiras, surgida em 2006 e despejada em 2014. Ver em: http://www.portomaravilha.com.br/conteudo/trump-towers-rio-chega-ao-porto-maravilha.aspx. Acesso em: 20/12/2012.

${ }^{28}$ Todos estes termos foram mencionados no Seminário citado. Ver nota 11.

${ }^{29}$ E que podemos associar às análises de Juliana Farias (2014), Farias e Vianna (2011), Farias (2014) e Márcia Leite (2012) a respeito da figura jurídica conhecida como auto de resistência, que favorece a acusação das vítimas da violência policial como responsáveis pela sua própria morte.

${ }^{30}$ Lembramos aqui o trecho de um discurso do governador Sérgio Cabral que nitidamente atribui uma diferença de natureza biológica aos moradores de favela em relação aos moradores dos bairros que ele reconhece como cidadãos: "Você pega o número de filhos por mãe na Lagoa Rodrigo de Freitas, Tijuca, Méier e Copacabana, é padrão sueco. Agora, pega na Rocinha. É padrão Zâmbia, Gabão. Isso é uma fábrica de produzir marginal" (Birman 2008).

${ }^{31}$ Sobre o papel das esticas na dinâmica do tráfico de drogas no Rio de Janeiro, seguimos os apontamentos de Barbosa (2012).

${ }^{32}$ Sobre este caso, ver Fernandes e Pierobon (2012).

${ }^{33}$ Os moradores da cidade do Rio de Janeiro, volta e meia, se deparam com imagens em que mortos e feridos em favelas da cidade são transportados em carrinhos da Comlurb. 


\section{Referências bibliográficas}

AGAMBEN, Giorgio. 2004. Homo sacer: o poder soberano e a vida nua I. Belo Horizonte: UFMG. . 2004a. Estado de exceção. São Paulo: Boitempo.

AGIER, Michel. 2008. Gérer les indésirables. Des camps de refugiés au gouvernement humanitaire. Paris: Editions Flammarion.

BARbOSA, Antonio Rafael. 2006. "O baile e a prisão - onde se juntam as pontas dos segmentos locais que respondem pela dinâmica do tráfico de drogas no Rio de Janeiro". Cadernos de Ciências Humanas - Especiaria, 9(15):119-135. . 2012. "Aviões, esticas e bocas de fumo: repressão a duas modalidades do comércio varejista de drogas presentes nas favelas e morros da região metropolitana do Rio de Janeiro". Anais da $32^{a}$ Reunião da ANPOCS, Caxambu. Mimeo.

BIONDI, Karina. 2010. Junto e misturado: uma etnografia do PCC. São Paulo: Editora Terceiro Nome.

BIRMAN, Patrícia. 2014. "Ocupações: territórios em disputa, gêneros e a construção de espaços comuns". In: Patrícia Birman, Márcia Leite, Carly Machado e Sandra Sá Carneiro (orgs.), Dispositivos urbanos e trama dos viventes: ordens e resistências. Rio de Janeiro: FGV (no prelo).

- 2012. "Cruzadas pela paz: práticas religiosas e projetos seculares relacionados à questão da violência no Rio de Janeiro". Religião e Sociedade, 32(1):209-226.

. 2008. "Favela é comunidade?". In: Luiz Antonio Machado da Silva (org.), Vida sob cerco: violência e rotina nas favelas do Rio de Janeiro. Rio de Janeiro: Faperj/ Nova Fronteira. pp. 99-114.
; LEITE, Márcia; MACHADO, Carly \& SÁ CARNEIRO, Sandra. 2014. "Introdução". In: __ (orgs.), Dispositivos urbanos e trama dos viventes: ordens e resistências. Rio de Janeiro: FGV (no prelo).

BRITTO, Adriana \& MENDES, Alexandre. 2011. "A defensoria pública e o direito à moradia no contexto dos megaeventos esportivos". Anais $1^{\circ}$ Seminário de Direito Urbanístico, Campos. pp. 1-22. Mimeo.

CHALHOUB, Sidney. 1996. Cidade febril: cortiços e epidemias na corte imperial. São Paulo: Companhia das Letras.

DAS, Veena. 2004. "The signature of the State. The paradox of ilegibility". In: Veena Das, Deborah Poole (eds.), Anthropology in the margins of the State. New Mexico: School of American Research Press. pp. 225-252. . ; POOLE, Deborah. 2004. "State and its margins: comparative ethnographies". In:___ (eds.), Anthropology in the margins of the State. New Mexico: School of American Research Press. pp. 3-33.

DELGADO, Manoel. 2007. La ciudad mentirosa. Fraude y miseria del modelo Barcelona. Madrid: Los Libros de la Catarata.

EPELE, Maria. 2010. Sujetar por la herida: una etnografia sobre drogas, pobreza y salud. Buenos Aires: Paidós.

FARIAS, Juliana. 2014. Governo de mortes: uma etnografia da gestão de populações de favelas no Rio de Janeiro. Tese de Doutorado, PPGSA/UFRJ, Rio de Janeiro.

FELTRAN, Gabriel. 2007. "Trabalhadores e bandidos: categorias de nomeação, significados políticos". Temáticas, 15:1-27.

. 2010. "Crime e castigo nas periferias da cidade: repertórios da justiça e 
a questão do homicídio nas periferias de São Paulo". Cadernos $\mathrm{CRH}$, 23(58):59-73.

FERGUSON, James. 2008. "Power topographies". In: David Nugent, Joan Vincent (eds.), A companion to the anthropology of politics. Oxford: Blackwell Publishing Ltd. pp. 383-399.

FERNANDES, Adriana. 2013. Escuta ocupação: arte do contornamento, viração e precariedade no Rio de Janeiro. Tese de Doutorado, PPCIS/UERJ, Rio de Janeiro.

. 2014. "Arte do contornamento e ocupação de moradia no Rio de Janeiro". Revista de Ciências Sociais Política e Trabalho, 40:311-333.

- 2014a. "Imagens da precariedade e figurações do Estado em ocupações de moradia no Rio de Janeiro". Anais do $38^{\circ}$ Encontro Anual da ANPOCS 2014. Mimeo.

.; PIEROBON, Camila. 2012. "Cotidiano da viração, engajamento e políticas públicas". Actas del Tercer Congreso Latinoamericano de Antropología - ALA, Santiago de Chile. pp. 1-12. Mimeo. FOUCAULT, Michel. 2009 [1975]. Vigiar e punir. Petrópolis: Editora Vozes. - 2008. Segurança, território, população. São Paulo: Martins Fontes. - 2008a. Nascimento da biopolítica. São Paulo: Martins Fontes.

GUIMARÃES, Roberta Sampaio. 2011.

A utopia da Pequena África: os espaços do patrimônio na Zona Portuária carioca. Tese de Doutorado, IFCS/UFRJ, Rio de Janeiro.

HIRATA, Daniel. 2014. "Comércio ambulante no Rio de Janeiro e em São Paulo: grupos de poder e instrumentos de governo contemporâneo". In: Patrícia Birman, Márcia Leite, Carly Machado e Sandra Sá Carneiro (orgs.), Dispositivos urbanos e trama dos viventes: ordens e resistências. Rio de Janeiro: FGV (no prelo).
LACERDA, Paula. 2012. "O caso dos meninos emasculados de Altamira": polícia, justiça e movimento social. Tese de Doutorado, MN/UFRJ, Rio de Janeiro.

LEITE, Márcia Pereira. 2012. "Da 'metáfora da guerra' ao projeto de 'pacificação': favelas e políticas de segurança pública no Rio de Janeiro". Revista Brasileira de Segurança Pública, 6(2):374-389. . 2014. "Entre a 'guerra' e a 'paz': Unidades de Polícia Pacificadora e gestão dos territórios de favela no Rio de Janeiro". In: Luiz Antonio Machado da Silva, Márcia Leite (orgs.), Dossiê Unidades de Polícia Pacificadora/ Cevis. Parte I. Dilemas. Vol. 7, n. 4. Disponível em: http:// www.dilemas.ifcs.ufrj.br/page_64.html. • ; MACHADO DA SILVA, Luís Antonio. 2013. "Circulação e fronteiras no Rio de Janeiro: a experiência urbana de jovens moradores de favelas em contextos de pacificação". In: Neiva Vieira Cunha, G. de Sanctis Feltran (orgs.), Sobre periferias: novos conflitos no Brasil contemporâneo. Rio de Janeiro: Lamparina/ Faperj. pp.146-158.

LOPES, Myrian. 2000. O Rio em movimento: quadros médicos e $(m)$ história 1890-1920. Rio de Janeiro: Fiocruz.

MACHADO, Carly. 2013. "É muita mistura: projetos religiosos, políticos, sociais, midiáticos, de saúde e segurança pública nas periferias do Rio de Janeiro". Religião e Sociedade, 33(2):13-36.

MACHADO DA SILVA, Luís Antonio (org). 2008. Vida sob cerco. Violência e rotina nas favelas do Rio de Janeiro. Rio de Janeiro: Nova Fronteira.

MAGALHÃES, Alexandre. 2013. Transformações no "problema favela" e a reatualização da remoção no Rio de Janeiro. Tese de Doutorado, IESP/UERJ, Rio de Janeiro.

MIAGUSKO, Edson. 2008. Movimentos de moradia e sem-teto em São Paulo: experiências no contexto do desmanche. Tese de Doutorado, Programa de 
Pós-Graduação em Sociologia, Universidade de São Paulo, São Paulo.

NACIF, Cristina; CARDOSO, Diego \& RIBEIRO, Maria. 2011. "Estado de Choque: legislação e conflitos no espaço público da cidade do Rio de Janeiro (1993-2010)". Anais - XIV Encontro Nacional da ANPUR, Rio de Janeiro. pp. 1-20. Mimeo.

OLIVEIRA, João Pacheco de. 2014. "Pacificação e tutela militar na gestão de populações e territórios". Mana. Estudos de Antropologia Social, 20(1):125-161. RIZEK, Cibele; CABANES, Robert; GEORGES, Isabel \& TELLES, Vera (orgs.). 2011. Saídas de emergência. Ganhar e perder a vida na periferia de São Paulo. São Paulo: Boitempo.

ROLNIK, Raquel. 2009. “Democracia no fio da navalha. Limites e possibilidades para a implementação de uma agenda de reforma urbana no Brasil". Revista Brasileira de Estudos Urbanos e Regionais, 11(2):31-50.

SANTOS, Natalia. 2012. Políticas da ordem: poder e imaginação na criação da cidade olímpica. Dissertação de Mestrado, IPPUR/UFRJ, Rio de Janeiro. SEVCENKO, Nicolau. 2003 [1983]. Literatura como missão/ Tensões sociais. São Paulo: Companhia das Letras.

TELLES, Vera. 2010. A cidade nas fronteiras do legal e ilegal. Belo Horizonte: Argumentum. . 2010a. "Nas dobras do legal e do ilegal: ilegalismos e jogos de poder nas tramas da cidade". Dilemas, 2(5-6): 97-126.

VIANNA, Adriana. 2014. "Violência, Estado e gênero: considerações sobre corpos e corpus entrecruzados". In: Antonio Carlos de Souza Lima, Virginia Garcia-Acosta (orgs.), Margens da violência. Subsídios ao estudo do problema da violência nos contextos mexicanos e brasileiros. Brasília: ABA. pp. 209-237.
.; FARIAS, Juliana. 2011. "A guerra das mães: dor e política em situações de violência institucional". Cadernos Pagu, 37(37):79-116.

WACQUANT, Loic. 2008. As duas faces do gueto. Trad. de Paulo Castanheira. São Paulo: Boitempo. 


\section{Resumo}

O antigo centro da cidade do Rio de Janeiro atualmente é alvo de uma política de reurbanização que visa minimizar ou mesmo eliminar dessa região as formas de trabalho, de comércio e de moradia populares que lhe garantiram até hoje uma grande vitalidade. A descrição etnográfica do processo de desmantelamento da vida social em curso nessa região enfocou primordialmente as dificuldades dos moradores para uma ocupação autogestionária, ali existente desde o início dos anos 2000. Analisamos esse processo através das formas de governabilidade postas em prática, que incluíram como um ator relevante o grupo do tráfico de drogas dominante na região. As consequências produzidas por esse megaprojeto, dirigido por um consórcio de empreiteiras e por atores públicos e privados associados ao governo do estado, tem como fio condutor o trabalho etnográfico efetuado na Ocupação Nelson Mandela. Palavras-chave Moradia popular/Ocupação, Tráfico de drogas, Violência, Ilegalismos, Precariedade, Estado.

\section{Abstract}

The old city centre of Rio de Janeiro is undergoing a reurbanization policy that aims to attenuate, or even eliminate, the popular character of its housing, commerce and employment, all of which confered upon this region great vitality. The present ethnographic description of this process of dismantling social life in the region focuses mainly on the hardships of the residents of a self-governing occupation, which has existed since the start of the 2000's. We analyse this process through the forms of governamentality put in practice, which requires that we include the group of dominant drug trade in the region as a relevant actor. The consequences produced by this mega enterprise, directed by a group of big contractors and by the government of Rio de Janeiro State, will be analysed through the ethnography of the "Nelson Mandela" Occupation.

Key words Popular housing/Occupation, Drug trade, Violence, Illegalisms, Precarity, State. 